\title{
PERANCANGAN PARKIR PINTAR BERTINGKAT MENGGUNAKAN METODE SMS GATEWAY
}

\author{
Sumarkantini* Lili Solihin, Woro Agus Nurtiyanto \\ Program Studi Teknik Elektro, Fakultas Teknik, Universitas Pamulang, Jl. Raya Puspiptek, Buaran, Kec. \\ Pamulang, Kota Tangerang Selatan, Banten. \\ *dosen01695@unpam.ac.id
}

\begin{abstract}
Smart multilevel parking with sms gateway method is a system designed to make it easier and faster for drivers to park their vehicles in the parking area, without searching for available parking, because this system is already equipped with a program that supports searching, place or takes a vehicle from or to a parking space that is automatically available for storage or collection. This system works through SMS communication between a cellphone or smartphone with an Arduino microcontroller using the GSM SIM800L module which functions as receiving SMS from parking users. The purpose of this research is the design and construction of a smart multi-store parking based miniature SMS gateway through several stages: Identification of needs, Requirement analysis, Hardware design, Software Design, Testing and operation of equipment. In hardware design consists of electronic design and mechanical design. While the software design consists of Arduino Due microcontroller programming design and HMI interface. Based on the results of tests that have been carried out, it is obtained that the multilevel smart parking system requires different time, where the average time is 38.57 seconds for the process of storing vehicles (access entry) and 38.83 seconds for the process of taking vehicles (access Exit). As for the SMS response, it takes an average of 3.35 seconds for indoors and 3.20 seconds for outdoors
\end{abstract}

Keywords: Smart parking, Microcontroller, SMS gateway

\begin{abstract}
ABSTRAK
Parkir pintar bertingkat bermetode sms gateway merupakan sistem yang dirancang agar mempermudah dan mempercepat para pengendara untuk memparkirkan kendaraannya di area parkir, tanpa mencari lahan parkir yang tersedia, karena sistem ini sudah dilengkapi dengan program yang mendukung untuk mencari, menempatkan atau mengambil kendaraan dari atau ke tempat lahan parkir yang tersedia secara otomatis untuk disimpan atau diambil. Sistem ini bekerja melalui komunikasi SMS antara Handphone atau Smartphone dengan mikrokontroler Arduino menggunakan modul GSM SIM800L yang berfungsi sebagai menerima SMS dari pengguna parkir. Tujuan dari penelitian ini adalah merancangan dan membangunan miniatur parkir pintar bertingkat berbasis SMS gateway melalui beberapa tahap yaitu : Identifikasi kebutuhan, Analisis kebutuhan, Perancangan perangkat keras, Perancangan perangkat lunak, Pengujian dan Pengoperasian alat. Pada perancangan perangkat keras terdiri dari rancangan elektronika dan rancangan mekanik. Sedangkan perancangan perangkat lunak terdiri dari rancangan pemrograman mikrokontroler Arduino Due dan interface HMI. Berdasarkan hasil pengujian yang telah dilaksanakan, diperoleh hasil bahwa sistem parkir pintar bertingkat membutuhkan waktu yang berbeda-beda, dimana waktu rata-rata selama 38,57 detik untuk proses penyimpanan kendaraan (akses masuk) dan 38,83 detik untuk proses pengambilan kendaraan (akses keluar). Sedangkan untuk respon SMS membutuhkan waktu rata-rata selama 3,35 detik untuk di dalam ruangan dan 3,20 detik untuk diluar ruangan.
\end{abstract}

Kata kunci: Parkir pintar, Mikrokontroler, SMS gateway. 


\section{PENDAHULUAN}

Perkembangan ilmu pengetahuan dan teknologi semakin maju, canggih dan berkembang pesat. Teknologi yang berkembang tidak hanya pada suatu bidang tertentu saja, tetapi semua bidang dalam kehidupan manusia. Salah satunya seperti bidang elektronika, robotik, otomotif, dan komunikasi. Kemajuan teknologi memberikan manfaat dan kemudahan bagi kehidupan manusia, salah satunya teknologi dibidang otomotif dan elektronika yang membuat mobil semakin canggih dan berkembang pesat. Selain itu kemajuan teknologi dibidang otomotif dan elektronika sangat memperhatikan kenyamanan dan keamanan di dalam mobil serta ramah lingkungan. Oleh karena itu tidak dapat dihindari, produksi mobil yang semakin bertambah pesat.

Seiring bertambahnya jumlah mobil saat ini, membuat kebutuhan lahan sebagai sarana parkir semakin meningkat. Peningkatan jumlah kendaraan yang akan menggunakan lahan parkir terkadang tidak diimbangi dengan ketersediaan lahan parkir, terutama parkir pada tempat umum seperti pasar tradisional, supermarket, rumah sakit, tempat ibadah dan sebagainya. Selain itu di Indonesia, urusan parkir kendaraan bisa dikatakan sangat memusingkan, karena di Indonesia masih kebanyakan menggunakan sistem parkir manual. Sistem parkir yang digunakan saat ini pada umumnya dilakukan dengan mengambil karcis atau kartu tanda masuk dan membayar dengan jumlah tertentu pada saat keluar. Setiap kali masuk ke tempat parkiran umum, terkadang sulit untuk menemukan tempat parkir kendaraan yang kosong karena petugas parkir yang tidak mengetahui dan tidak menginformasikan lahan parkir yang masih tersedia di area parkir secara pasti. Berdasarkan pengalaman penulis jika diperhitungkan, waktu untuk memparkirkan kendaraan memerlukan waktu 3 hingga 10 menit untuk mendapatkan lahan parkir.

Untuk mengatasi itu semua, maka perlu dibuat sistem parkir pintar berbasis teknologi yang mengedepankan unsur objektifitas dan mampu mengatasi setiap permasalahan yang disebutkan diatas. Salah satu solusi yang menarik untuk membangun sistem tersebut adalah dengan membangun lahan parkir yang bertingkat menggunakan sistem penyimpanan otomatis yang digerakkan oleh motor - motor yang dikontrol oleh Mikrokontroler dengan sistem komunikasi SMS (Short Message Service). 
Penelitian ini bertujuan untuk merancang parkir pintar bertingkat menggunakan metode SMS Gateway. Dengan harapan untuk mempermudah dan mempercepat para pengendara untuk memparkirkan kendaraannya di area parkir.

Metode riset yang digunakan,yaitu dengan melakukan studi literatur dilakukan dengan membaca buku panduan (manual book) dari setiap komponen yang dipakai atau pembaharuan konsep sistem yang bersumber dari buku-buku, data sheet komponen dan artikel dari internet. Perancangan sistem dilakukan dengan menentukan alat yang dibutuhkan dan mencari spesifikasinya, serta Observasi dilakukan dengan menguji kinerja alat untuk memperoleh data melalui pendekatan praktik sehingga data yang ditulis dapat diakui secara objektif, akurat dan realible.

\section{METODOLOGI}

\subsection{Deskripsi alat}

Pada perancangan dan pembuatan parkir pintar bertingkat menggunakan metode SMS gateway, dibagi menjadi perancangan perangkat keras (hardware) terdiri dari bagian control panel yang menggunakan HMI sebagai interface. Kemudian bagian main control menggunakan Arduino Due R3 ARM sebagai kontrol utama untuk membaca data, menyimpan data dan mengendalikan sistem parkir pintar bertingkat. Sedangkan bagian slave control yang menggunakan Modul GSM Sim800L digunakan sebagai komunikasi antara pengguna parkir dengan alat ini melalui sistem SMS gateway. Software Arduino IDE digunakan untuk memprogram main control pada Arduino Due R3 ARM dan Software Nextion Editor untuk mendesign interface pada HMI.

\subsection{Blok Diagram}

Pada blok diagram parkir pintar bertingkat, menjelaskan fungsi dari sistem secara umum. Blok diagram tersebut terdiri dari 9 bagian blok yaitu Control Panel, Main Control, Slave Control, Output Motor, Output Sound, Sensor Detektor, Sensor Limit, Power Supply dan User. Penjelasannya sebagai berikut :

\section{Control Panel}

Bagian Control Panel Terdiri dari komponen utama, yaitu HMI sebagai interface yang dapat dikontrol oleh pengguna, untuk akses masuk dan keluar pada parkir 
pintar. Data perintah tersebut akan dikirim ke miktrokontroler Arduino pada bagian main control sebagai master unit control.

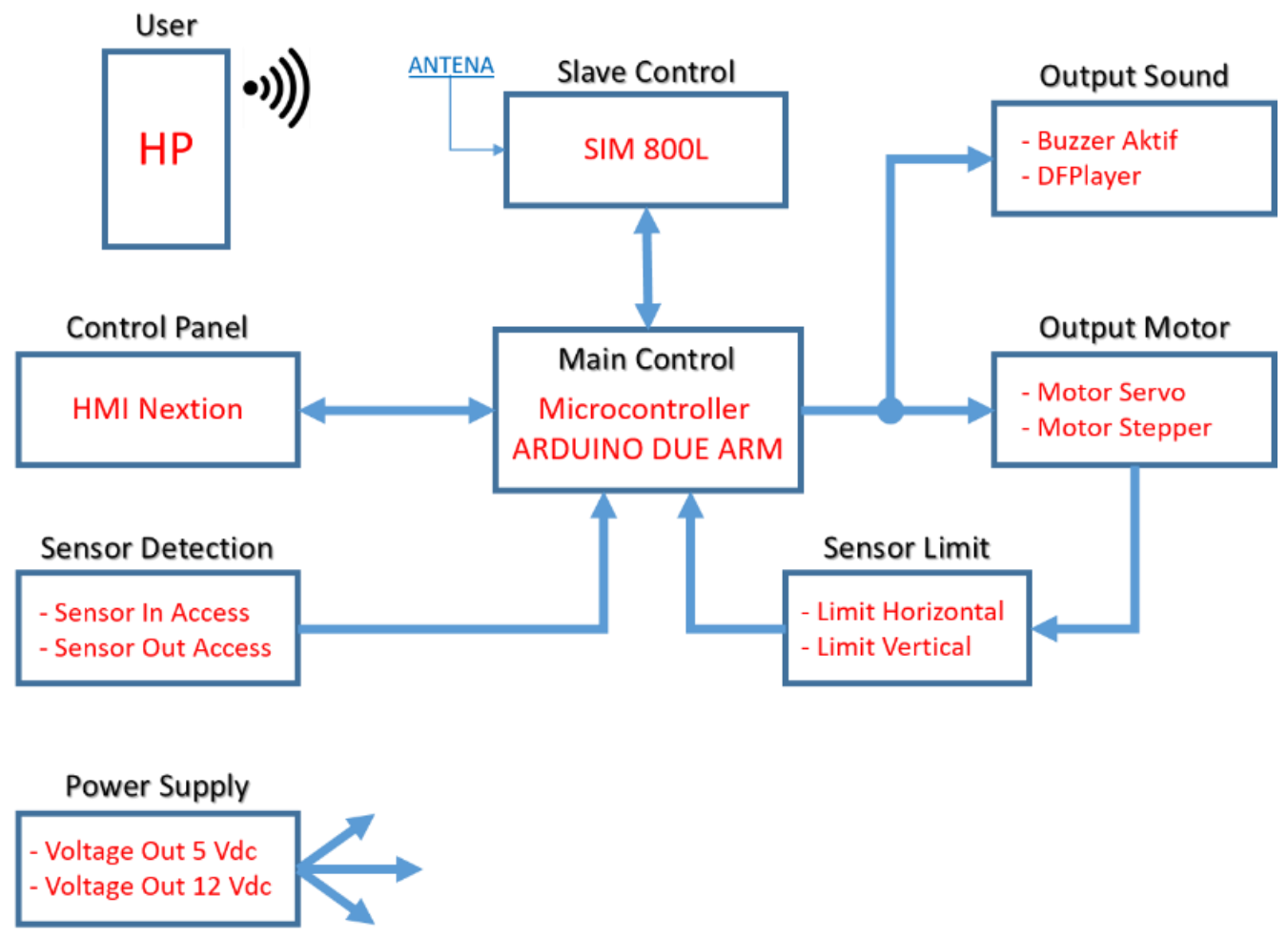

Gambar 1. Blok diagram parkir pintar bertingkat

\section{Main Control}

Bagian Main Control adalah bagian utama dari keseluruhan sistem yang ada. Bagian Main Control Terdiri dari Mikrokontroler Arduino Due R3 ARM sebagai master unit control yang berfungsi sebagai pembaca, pemroses, penyimpan dan pengeksekusi data utama dari input dan output seperti bagian sensor, slave control, control panel serta output.

3. Slave Control

Bagian Slave Control Terdiri dari Modul GSM SIM800L sebagai perantara komunikasi antara pengguna parkir dengan alat ini melalui sistem SMS gateway pada akses masuk dan akses keluar.

\section{Output Motor}

Bagian Output Motor Terdiri dari 6 Motor Servo dan 3 Motor Stepper. Dimana Motor Servo berfungsi sebagai kendali lengan robot seperti capit palet, pergerakan maju dan mundur capit, pergerakan lengan capit, naik dan turun pintu serta portal masuk dan 
portal keluar. Sedangkan Motor Stepper berfungsi untuk pergerakan mekanik horizontal (kiri - kanan) menggunakan 1 motor stepper dan pergerakan mekanik vertikal (atas - bawah) menggunakan 2 motor stepper. Driver yang digunakan pada motor stepper adalah DRV8825.

\section{Output Sound}

Bagian Output Sound terdiri dari buzzer dan spaker. Dimana buzzer berfungsi sebagai indikator suara dengan bunyi beep ketika sistem ini mendeteksi adanya mobil atau pengguna. Sedangkan speaker berfungsi sebagai menyampaikan informasi mengenai parkir. Pada output speaker membutuhkan penguat amplifier dan DFPlayer sebagai pembaca data memori SD card dengan format mp3.

6. Sensor Deteksi

Bagian sensor deteksi terdiri dari sensor infrared dan photodioda yang berfungsi untuk mendeteksi adanya mobil sebagai akses masuk pada sensor 1 yang diletakan pada area palet parkir dan mendeteksi adanya pengguna sebagai akses ke luar pada sensor 2 yang diletakkan pada area Control Panel. Bagian ini adalah bagian awal untuk menentukan akses mana yang harus di kehendaki.

\section{Sensor Limit}

Bagian Sensor Limit terdiri dari limit switch yang berfungsi sebagai pembatas pergerakan motor stepper baik pergerakan mekanik horizontal maupun vertikal.

8. Power Supply

Bagian power supply terdiri dari power supply switching dengan tegangan $12 \mathrm{~V}$ untuk power supply Motor Stepper, Amplifier Sound sistem dan tegangan 5V untuk power supply Motor Servo, Arduino Arduino Due R3 ARM, HMI dan Modul GSM SIM 800L serta sensor yang digunakan.

9. User

Bagian User terdiri dari Handphone Pengguna, yang akan digunakan ketika menggunakan parkir pintar bertingkat pada saat akses masuk maupun akses keluar dengan metode sms gateway.

\subsection{Diagram alir Parkir Pintar Bertingkat}

Diagram alir pada sistem parkir pintar bertingkat, mulai dari kondisi mati dan standby, proses sistem akses masuk dan proses sistem akses keluar pada kendaraan. 


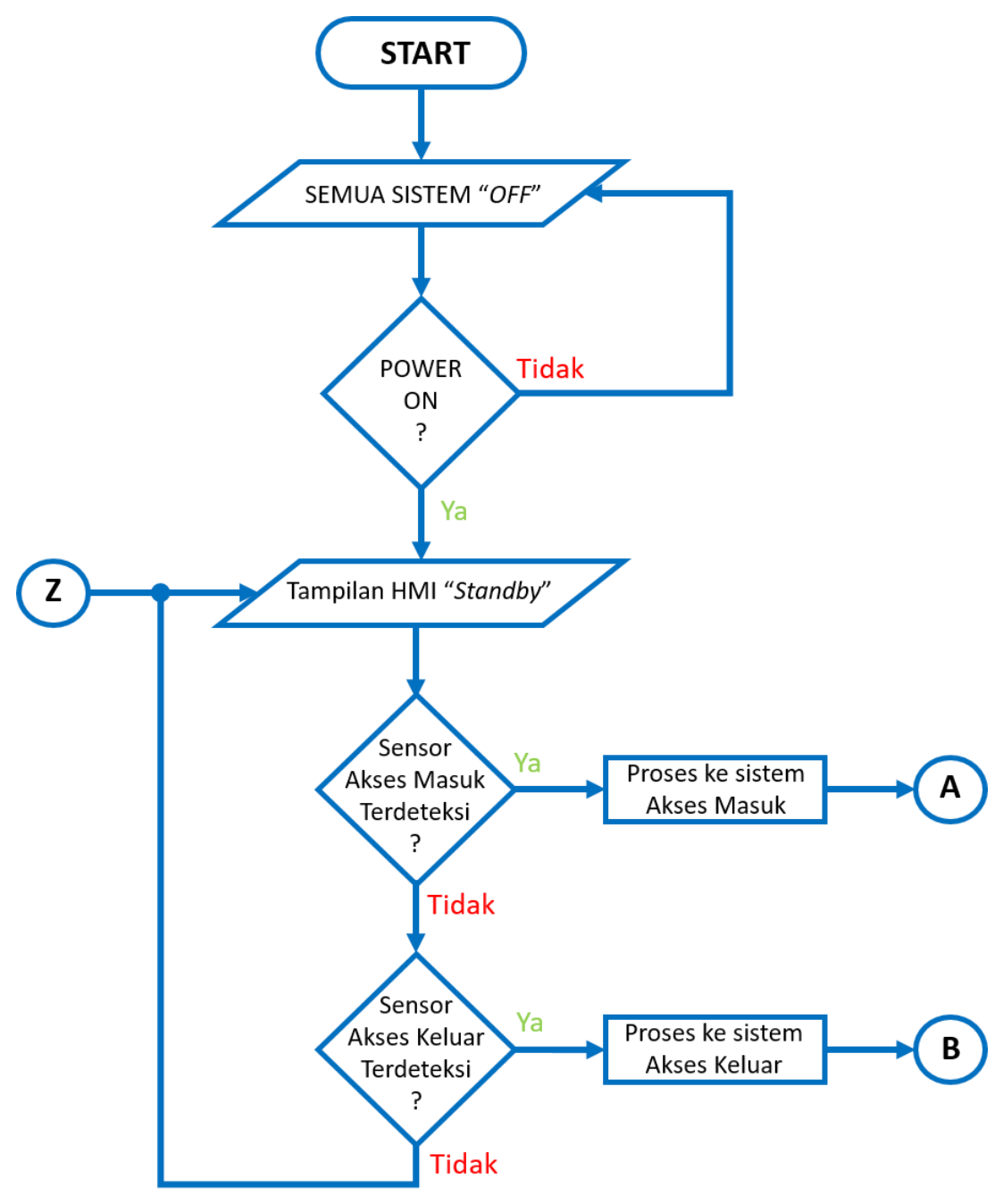

Gambar 2. Flowchart parkir pintar bertingkat dengan kondisi mati dan standby

Pada saat kondisi mati, sistem menunggu untuk penekanan tombol power ke on, yang berfungsi untuk mengaktifkan sistem menjadi kondisi standby, ketika kondisi standby maka display HMI akan aktif dengan mengeluarkan gambar yang bertulisan standby. Kemudian apabila ada penekanan tombol power ke off pada kondisi standby, maka kondisi tersebut berubah menjadi mati dan display HMI akan non aktif (tidak ada gambar). Ketika kondisi standby, sistem menunggu untuk adanya deteksi pada sensor infrared. Jika sensor infrared terlebih dahulu mendeteksi kendaraan, maka sistem akan memerintahkan kondisi proses ke sistem akses masuk (A) dan jika mendeteksi adanya pengguna (user), maka kondisi proses ke sistem akses keluar (B). Sistem ini akan memprioritaskan akses masuk terlebih dahulu. 


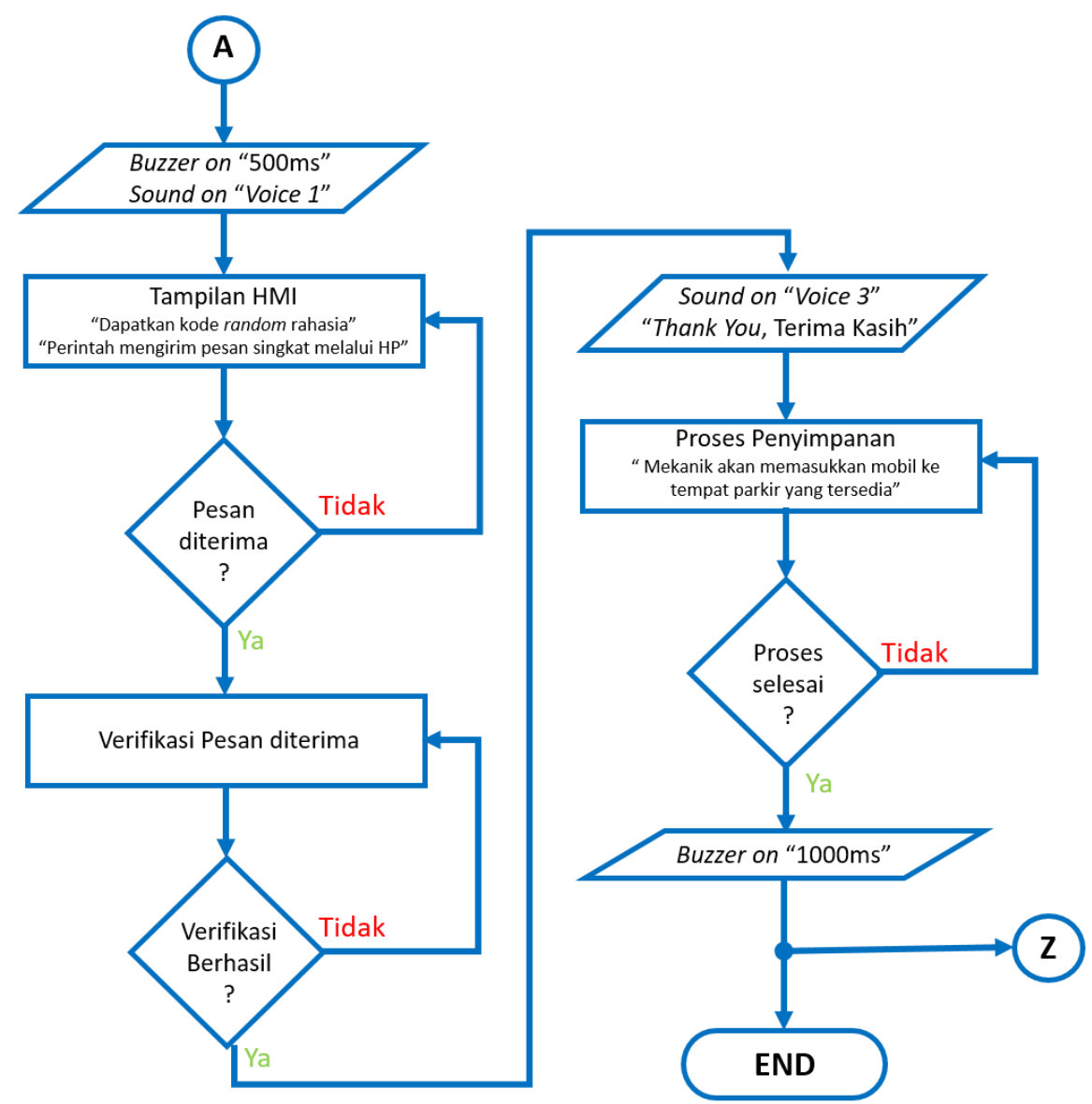

Gambar 3. Flowchart parkir pintar bertingkat dengan proses akses masuk

Pada saat masuk kondisi proses ke sistem akses masuk (A) maka buzzer akan bunyi "beep" selama 500ms (setengah detik) kemudian mati dan dilanjutkan dengan suara "voice 1" yang berbunyi "Welcome to smart parking sistem, Get a random secret code and send a short message by phone, Thank you" kemudian pengemudi diminta untuk turun serta seluruh penumpang yang ada pada kendaraan tersebut dan mendekat ke HMI sebagai control panel. Display HMI akan menampilkan 3 digit kode rahasia secara random. dan memerintahkan untuk mengirim pesan melalui smartphone / handphone. Kemudian menunggu pengguna untuk mengirim pesan tersebut, jika sudah dibaca oleh sistem, maka hasil baca tersebut akan dilakukan verifikasi, dan apabila verifikasi berhasil maka suara "voice 3" akan berbunyi "Thank you, Terima kasih". Ketika itu juga, kendaraan tersebut akan dimasukan langsung ke tempat lahan parkir yang kosong dan mengambil palet kosong pada lahan parkir yang tersedia untuk diisi kendaraan berikut, kemudian ketika sistem selesai memproses maka buzzer akan aktif 1000ms (1 detik) setelah itu sistem kembali standby $(\mathrm{Z})$. 


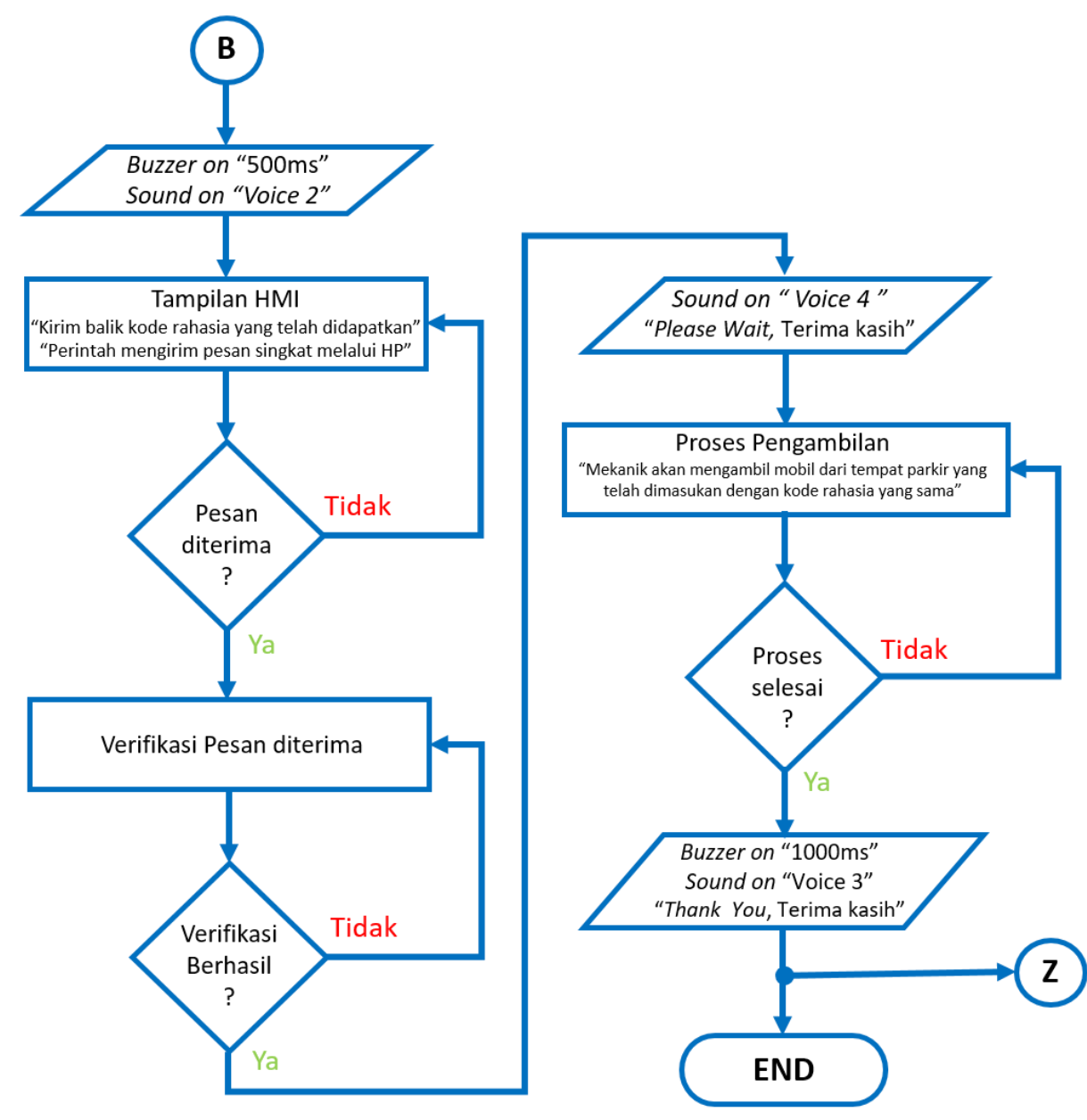

Gambar 4. Flowchart parkir pintar bertingkat dengan proses akses keluar

Pada saat masuk kondisi proses ke sistem akses keluar (B) maka buzzer akan bunyi "beep" selama 500ms (setengah detik) kemudian mati dan dilanjutkan dengan suara "voice 2" yang berbunyi "Welcome to smart parking sistem, Send back the secret code that you got and send a short message by phone, Thank you“. Display HMI akan menampilkan perintah untuk mengirimkan kembali kode rahasia yang telah didapatkan ketika akses masuk melalui pesan singkat smartphone / handphone. Kemudian menunggu pengguna untuk mengirim pesan tersebut, jika sudah dibaca oleh sistem, maka hasil baca tersebut akan dilakukan verifikasi, dan apabila verifikasi berhasil maka suara "voice 4" akan berbunyi "Please Wait, Thank you". Ketika itu juga, palet yang kosong akan dimasukan ke lokasi awal dan kendaraan yang disimpan sebelumnya, akan diambil dan dibawa ke pintu keluar pada parkir. kemudian suara "voice 3" akan berbunyi "Thank you" dan buzzer akan aktif 1000ms (1 detik) kemudian sistem selesai memproses dan kembali standby (C) dan pengemudi dapat mengambil kendaraan tersebut. 


\subsection{Perancangan Perangkat Keras}

Pada perancangan perangkat keras penulis menggunakan software Autodesk Inventor Profesional sebagai design mekanik pada parkir pintar bertingkat dan software Altium Designer sebagai desain elektroniknya.

\subsection{Software Altium Designer}

Software Altium Designer membantu penulis untuk mendesain bagian elektronik sistem parkir pintar bertingkat.

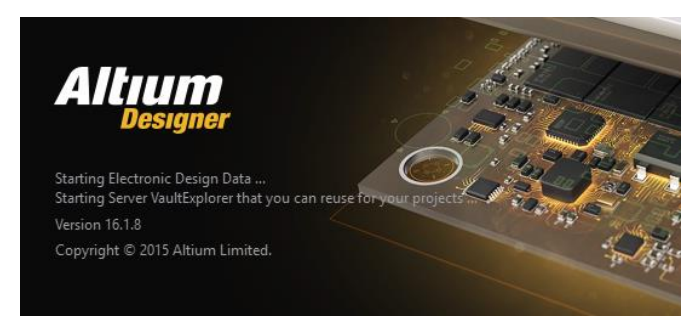

Gambar 5. Tampilan Awal Altium Designer

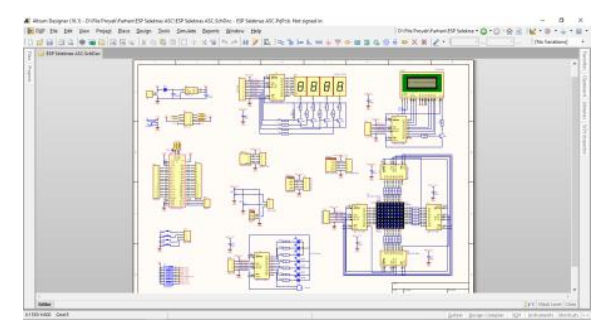

Gambar 6. Desain Skematik Altium Designer

\subsection{Software Autodesk Inventor Profesional}

Software Autodesk Inventor membantu penulis untuk mendesain perangkat mekanik untuk penggerak sistem parkir pintar bertingkat. Dimana setelah penulis mendesain dari inventor, penulis langsung mencetak hasil prototype desainnya menggunakan 3D Printing.

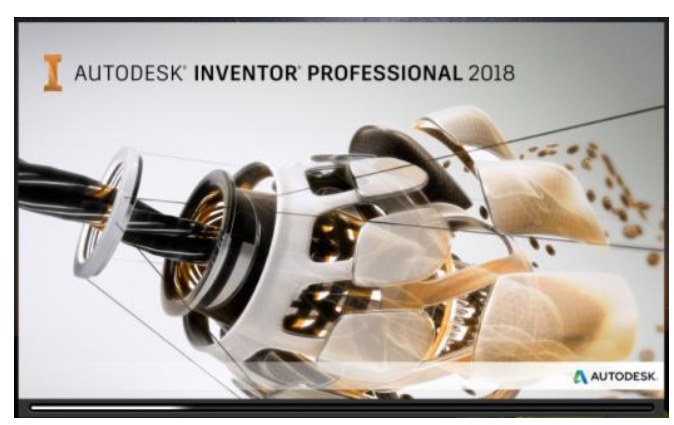

Gambar 7. Tampilan Awal Autodesk Inventor

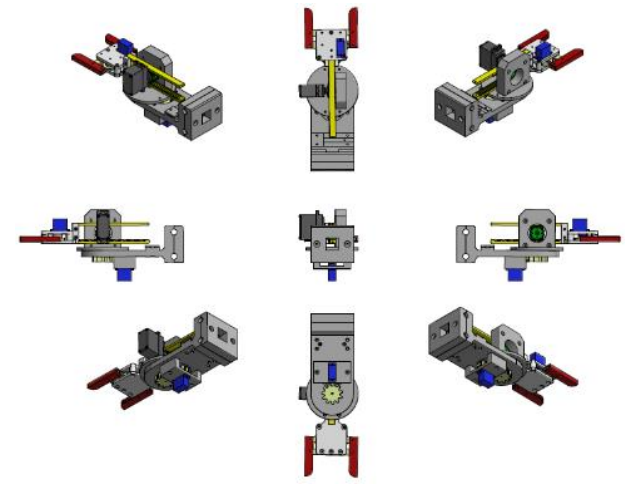

Gambar 8. Desain Capit pada Autodesk Inventor 


\subsection{Hasil dari Perancangan Mekanik}
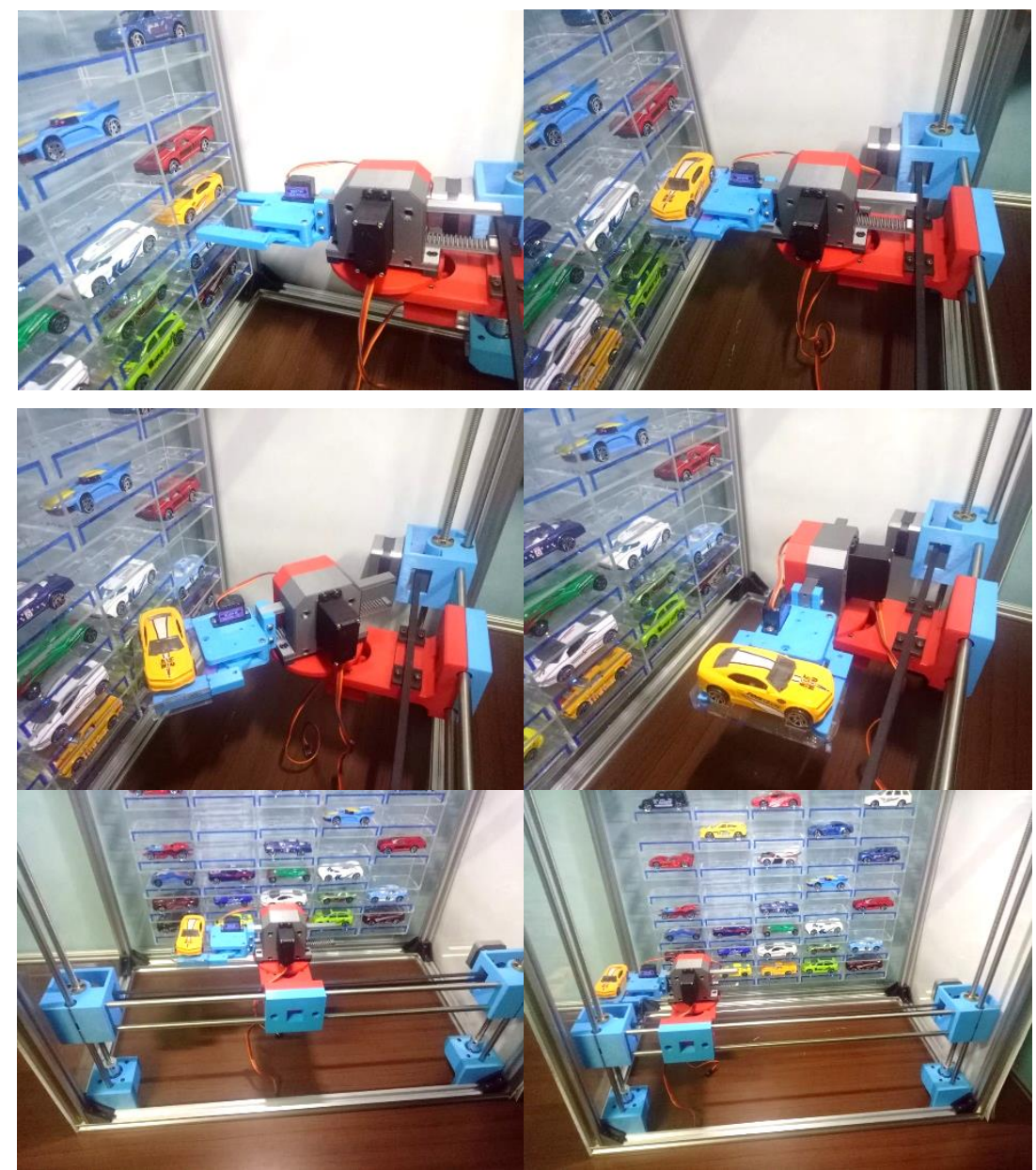

Gambar 9. Hasil perancangan mekanik.

\subsection{Perancangan Perangkat Lunak}

Pada perancangan perangkat lunak penulis hanya menggunakan software Arduino IDE sebagai design program kontrol pada Mikrokontroler Arduino Due R3 ARM kemudian software Nextion Editor sebagai desain interface pengguna dengan alat untuk akses masuk dan akses keluar.

\subsection{Software Arduino IDE}

Mikrokontroler Arduino Due R3 ARM adalah komponen kendali utama pada sistem ini dan dapat menjalankan semua perintah yang telah di tanamkan pada mikrokontroler tersebut berfungsi untuk menjalankan dan mengoperasikan alat parkir pintar bertingkat. Pembuatan program menggunakan bantuan dari software Arduino IDE 
sebagai program pengontrolan yang akan ditanamkan ke Mikrokontroler Arduino Due R3 ARM menggunakan bahasa $\mathrm{C}$.

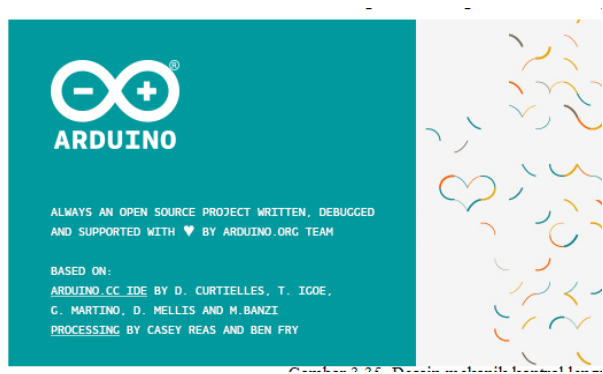

Gambar 10. Tampilan Awal Arduino

IDE

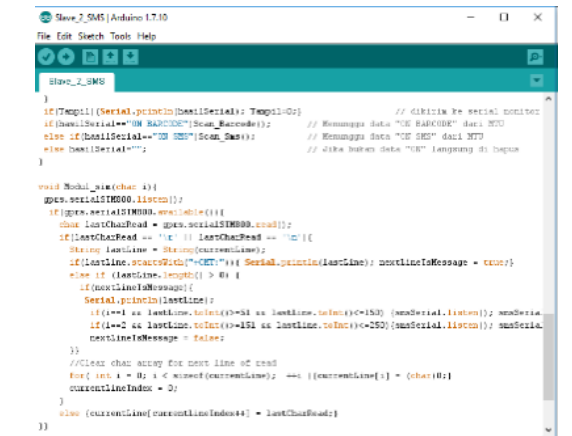

Gambar 11. Design software pada arduino IDE

\subsection{Software Nextion Editor}

HMI yang digunakan adalah HMI Nextion 3,5" HMI UART LCD TFT + Touchscreen 480x320 px for Arduino dan HMI ini dapat menyampaikan informasi mengoperasikan alat serta melakukan tampilan dalam mambantu pengguna untuk mendapatkan akses masuk dan akses keluar. Pembuatan rancangan display interface menggunakan bantuan dari software Nextion Editor sebagai desain interface pada display HMI. Berikut ini adalah perancangan untuk desain display HMI dengan software nextion editor.

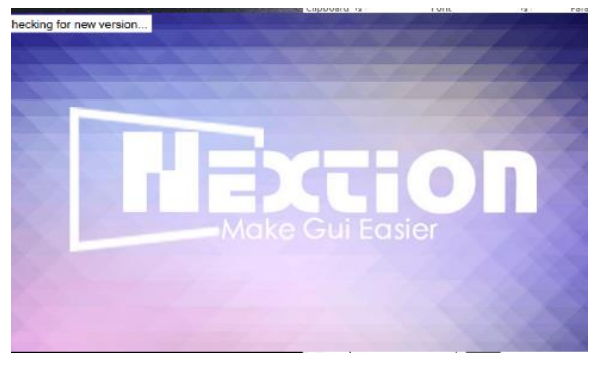

Gambar 12. Tampilan Awal Software Nextion Editor

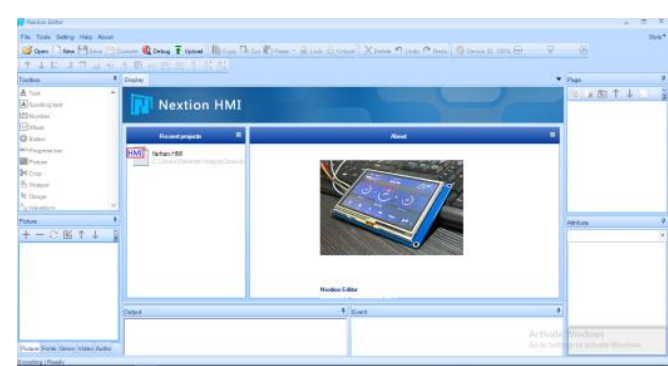

Gambar 13. Design software Nextion

Editor

\subsection{Hasil Dari Perancangan Antarmuka HMI Pada Smart Parking System}

1. Perancangan tampilan cover

Tampilan ini adalah tampilan awal saat mesin dijalankan. Disini tidak ada proses terjadi melainkan pemberitahuan nama alat, dan instansi penulis. 


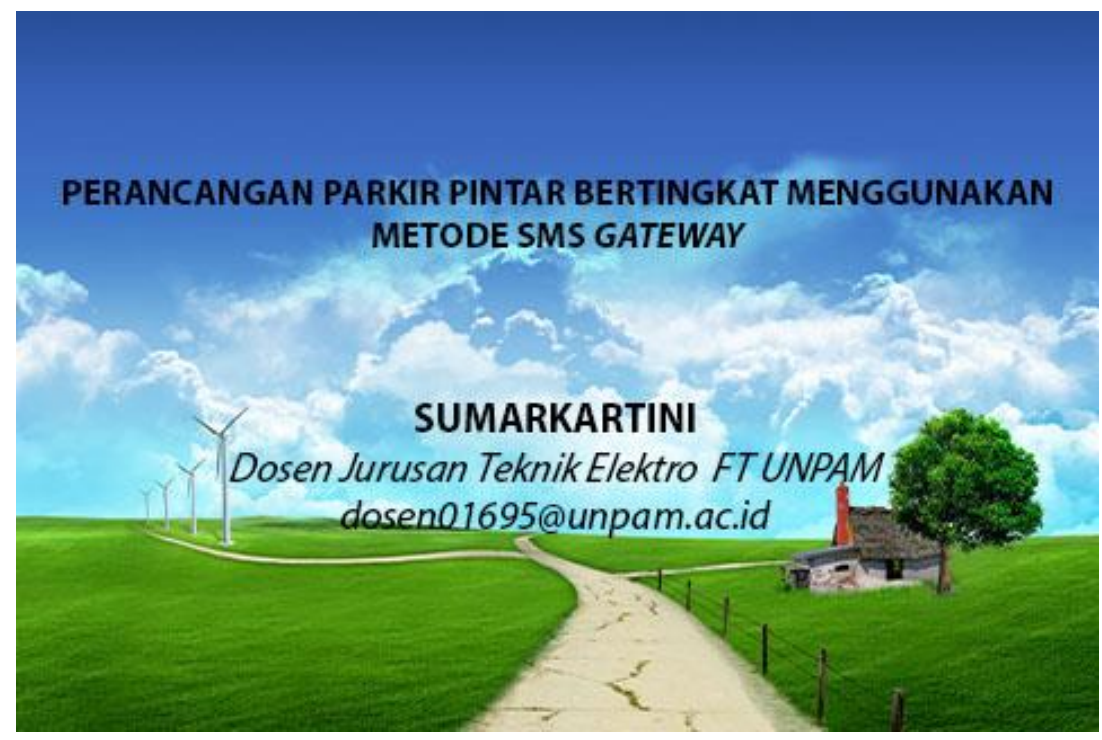

Gambar 14. Perancangan tampilan Cover

2. Perancangan tampilan akses masuk

Tampilan ini adalah tampilan yang menginstruksikan pengguna untuk menggambil kode rahasia dan diminta untuk SMS menggunakan Hp pengguna.

3. Perancangan tampilan akses keluar

Tampilan ini adalah tampilan yang menginstruksikan pengguna untuk mengirimkan kembali kode rahasia yang sudah didapatkan sebelumnya melalui SMS menggunakan Hp pengguna.

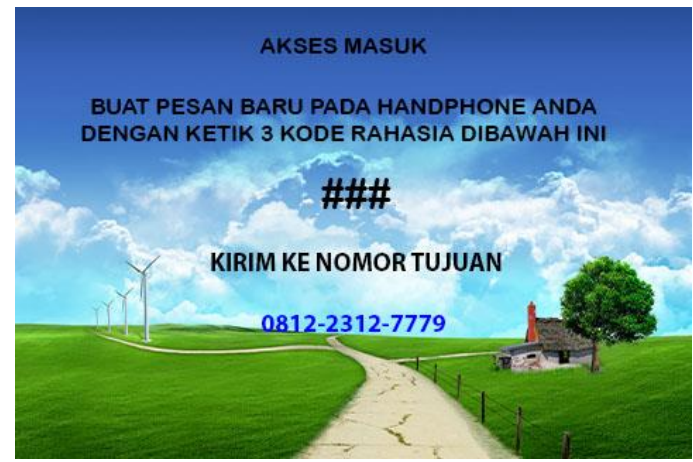

Gambar 15. Perancangan tampilan akses masuk

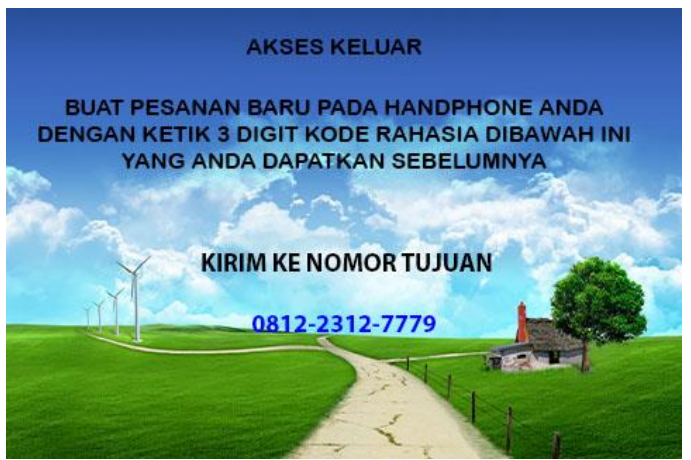

Gambar 16. Perancangan tampilan akses keluar

\section{HASIL DAN PEMBAHASAN}

\subsection{Hasil Rancang Bangun}

Berikut adalah hasil dari perancangan pembuatan miniatur parkir pintar bertingkat. 


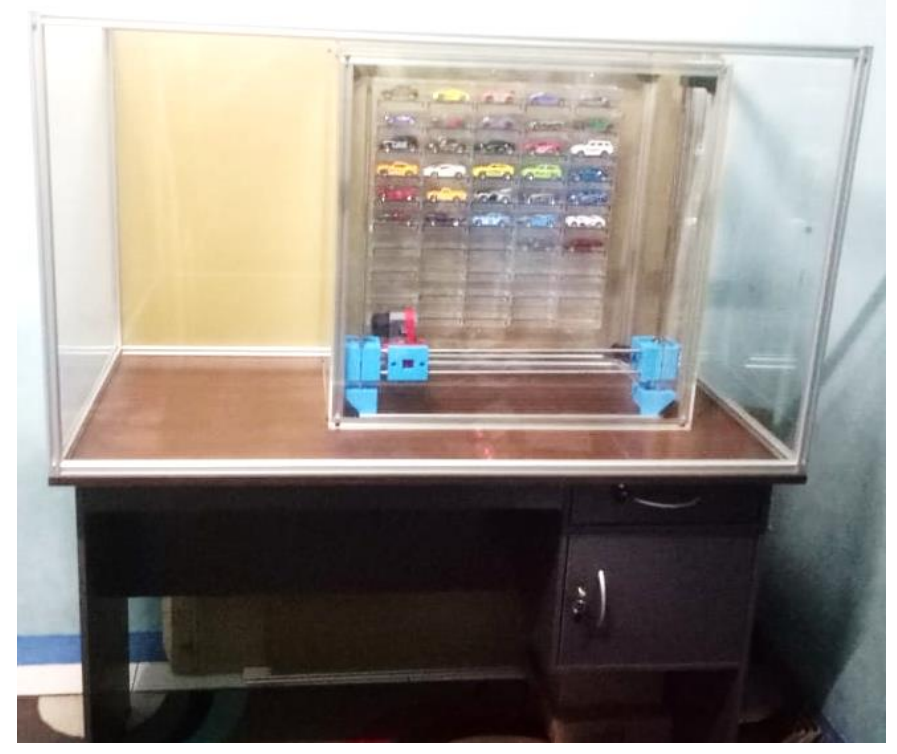

Gambar 17. Hasil perancangan dan pembuatan alat

\subsection{Pengujian Parkir Bertingkat}

Berikut adalah gambar lokasi penyimpanan parkir pintar bertingkat bertujuan untuk mengetahui koordinat atau lokasi parkir pada saat pengujian. Dimana lahan parkir memiliki 10 lantai dengan setiap lantai memiliki 5 ruangan. Pada sistem ini, parkir akan mengisi bagian bawah terlebih dahulu mulai dari lantai 1 ruang 1 (L1 R1) hingga lantai 1 ruang 5 (L1 R5), kemudian dilanjutkan ke lantai 2 hingga lantai 10 dan berakhir pada lantai 10 ruang 5 (L10 R5).

\begin{tabular}{|c|c|c|c|c|}
\hline $\begin{array}{c}\text { PENYIMPANAN } \\
\text { L10 R1 }\end{array}$ & $\begin{array}{c}\text { PENYIMPANAN } \\
\text { L10 R2 }\end{array}$ & $\begin{array}{c}\text { PENYIMPANAN } \\
\text { L10 R3 }\end{array}$ & $\begin{array}{c}\text { PENYIMPANAN } \\
\text { L10 R4 }\end{array}$ & $\begin{array}{c}\text { PENYIMPANAN } \\
\text { L10 R5 }\end{array}$ \\
\hline $\begin{array}{c}\text { PENYIMPANAN } \\
\text { L9 R1 }\end{array}$ & $\begin{array}{c}\text { PENYIMPANAN } \\
\text { L9 R2 }\end{array}$ & $\begin{array}{c}\text { PENYIMPANAN } \\
\text { L9 R3 }\end{array}$ & $\begin{array}{c}\text { PENYIMPANAN } \\
\text { L9 R4 }\end{array}$ & $\begin{array}{c}\text { PENYIMPANAN } \\
\text { L9 R5 }\end{array}$ \\
\hline $\begin{array}{c}\text { PENYIMPANAN } \\
\text { L8 R1 }\end{array}$ & $\begin{array}{c}\text { PENYIMPANAN } \\
\text { L8 R2 }\end{array}$ & $\begin{array}{c}\text { PENYIMPANAN } \\
\text { L8 R3 }\end{array}$ & $\begin{array}{c}\text { PENYIMPANAN } \\
\text { L8 R4 }\end{array}$ & $\begin{array}{c}\text { PENYIMPANAN } \\
\text { L8 R5 }\end{array}$ \\
\hline $\begin{array}{c}\text { PENYIMPANAN } \\
\text { L7 R1 }\end{array}$ & $\begin{array}{c}\text { PENYIMPANAN } \\
\text { L7 R2 }\end{array}$ & $\begin{array}{c}\text { PENYIMPANAN } \\
\text { L7 R3 }\end{array}$ & $\begin{array}{c}\text { PENYIMPANAN } \\
\text { L7 R4 }\end{array}$ & $\begin{array}{c}\text { PENYIMPANAN } \\
\text { L7 R5 }\end{array}$ \\
\hline $\begin{array}{c}\text { PENYIMPANAN } \\
\text { L6 R1 }\end{array}$ & $\begin{array}{c}\text { PENYIMPANAN } \\
\text { L6 R2 }\end{array}$ & $\begin{array}{c}\text { PENYIMPANAN } \\
\text { L6 R3 }\end{array}$ & $\begin{array}{c}\text { PENYIMPANAN } \\
\text { L6 R4 }\end{array}$ & $\begin{array}{c}\text { PENYIMPANAN } \\
\text { L6 R5 }\end{array}$ \\
\hline $\begin{array}{c}\text { PENYIMPANAN } \\
\text { L5 R1 }\end{array}$ & $\begin{array}{c}\text { PENYIMPANAN } \\
\text { L5 R2 }\end{array}$ & $\begin{array}{c}\text { PENYIMPANAN } \\
\text { L5 R3 }\end{array}$ & $\begin{array}{c}\text { PENYIMPANAN } \\
\text { L5 R4 }\end{array}$ & $\begin{array}{c}\text { PENYIMPANAN } \\
\text { L5 R5 }\end{array}$ \\
\hline $\begin{array}{c}\text { PENYIMPANAN } \\
\text { L4 R1 }\end{array}$ & $\begin{array}{c}\text { PENYIMPANAN } \\
\text { L4 R2 }\end{array}$ & $\begin{array}{c}\text { PENYIMPANAN } \\
\text { L4 R3 }\end{array}$ & $\begin{array}{c}\text { PENYIMPANAN } \\
\text { L4 R4 }\end{array}$ & $\begin{array}{c}\text { PENYIMPANAN } \\
\text { L4 R5 }\end{array}$ \\
\hline $\begin{array}{c}\text { PENYIMPANAN } \\
\text { L3 R1 }\end{array}$ & $\begin{array}{c}\text { PENYIMPANAN } \\
\text { L3 R2 }\end{array}$ & $\begin{array}{c}\text { PENYIMPANAN } \\
\text { L3 R3 }\end{array}$ & $\begin{array}{c}\text { PENYIMPANAN } \\
\text { L3 R4 }\end{array}$ & $\begin{array}{c}\text { PENYIMPANAN } \\
\text { L3 R5 }\end{array}$ \\
\hline $\begin{array}{c}\text { PENYIMPANAN } \\
\text { L2 R1 }\end{array}$ & $\begin{array}{c}\text { PENYIMPANAN } \\
\text { L2 R2 }\end{array}$ & $\begin{array}{c}\text { PENYIMPANAN } \\
\text { L2 R3 }\end{array}$ & $\begin{array}{c}\text { PENYIMPANAN } \\
\text { L2 R4 }\end{array}$ & $\begin{array}{c}\text { PENYIMPANAN } \\
\text { L2 R5 }\end{array}$ \\
\hline $\begin{array}{c}\text { PENYIMPANAN } \\
\text { L1 R1 }\end{array}$ & $\begin{array}{c}\text { PENYIMPANAN } \\
\text { L1 R2 }\end{array}$ & $\begin{array}{c}\text { PENYIMPANAN } \\
\text { L1 R3 }\end{array}$ & $\begin{array}{c}\text { PENYIMPANAN } \\
\text { L1 R4 }\end{array}$ & $\begin{array}{c}\text { PENYIMPANAN } \\
\text { L1 R5 }\end{array}$ \\
\hline
\end{tabular}

Gambar 18.Sistem Lokasi Penyimpanan Kendaraan

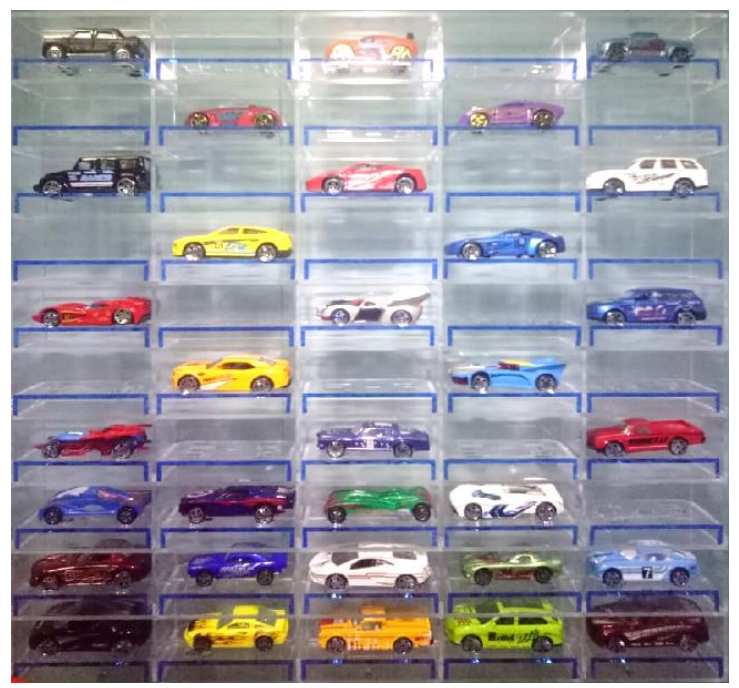

Gambar 19.Prototype Lokasi

Penyimpanan Kendaraan 


\subsection{Pengujian Akses Masuk Kendaraan}

Langkah Pengujian :

1. Pastikan Alat dalam kondisi hidup dengan mode Standby.

2. Masukkan kendaraan ke area parkir hingga terdeteksi oleh sensor 1 hingga bunyi buzzer 500ms (setengah detik).

3. Tunggu informasi suara akses masuk selesai sekitar 4 detik.

4. Pengguna kendaraan silakan keluar dari kendaraannya yang mau di parkirkan.

5. Tulis dan kirim SMS sesuai perintah dari interface HMI.

6. Tunggu beberapa saat hingga terdengar informasi suara "Thank You".

7. Hitunglah proses penyimpanan kendaraan berdasarkan waktu menggunakan stopwatch dari awal penarikan palet yang ada kendaraannya hingga pengeluaran palet yang tidak ada kendaraannya hingga buzzer bunyi 1000ms (1 detik) dan Sistem kembali ke kondisi standby.

8. Catat hasil pengujian akses masuk kemudian ulangi lagi hingga tempat parkir penuh dengan kendaraan.

Dari hasil pengujian akses masuk atau penyimpanan kendaraan, dimana setiap akses masuk membutuhkan waktu yang berbeda-beda, tergantung lokasi penyimpanan kendaraan. Status dikatakan sukses ketika smartparking berhasil menaruh kendaraan dan mengambil palet. Rata-rata waktu yang dibutuhkan untuk proses penyimpanan ditempuh selama 38,57 detik dengan waktu tercepat ditempuh selama 29,48 detik pada lokasi parkir L1 R4 serta ambil palet L1 R5. Sedangkan waktu terlama ditempuh selama 47,27 detik pada parkir L9 R5 serta ambil palet L10 R1. Berikut ini adalah gambar grafik dari pengujian akses masuk.

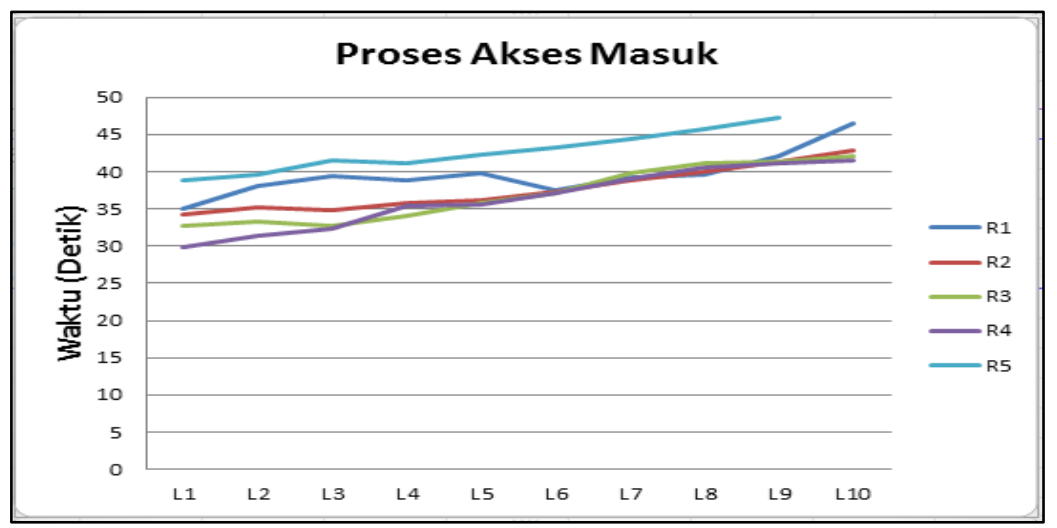

Gambar 20. Grafik pengujian akses masuk 


\subsection{Pengujian Akses Keluar Kendaraan}

Langkah Pengujian :

1. Pastikan Alat dalam kondisi hidup dengan mode Standby.

2. Dekatkan tangan anda pada sensor 2 hingga terdeteksi oleh sensor 2 hingga bunyi buzzer 500ms (setengah detik).

3. Tunggu informasi suara akses keluar selesai sekitar 4 detik.

4. Tulis dan kirim SMS sesuai perintah dari interface HMI.

5. Tunggu beberapa saat hingga terdengar informasi suara "Please Wait, Thank You".

6. Hitunglah proses pengambilan kendaraan berdasarkan waktu menggunakan stopwatch dari awal penarikan palet yang tidak ada kendaraannya hingga pengeluaran palet yang ada kendaraannya beserta suara "Thank you" dan buzzer bunyi 1000ms (1 detik) dan Sistem kembali ke kondisi standby.

7. Catat hasil pengujian akses keluar, kemudian ulangi lagi hingga tempat parkir kondisi kosong.

Dari hasil pengujian akses keluar atau pengambilan kendaraan, dimana setiap akses keluar membutuhkan waktu yang berbeda - beda, tergantung lokasi penyimpanan kendaraan. Status dikatakan sukses ketika smartparking berhasil menaruh palet dan mengambil kendaraan. Rata-rata waktu yang dibutuhkan untuk proses penyimpanan ditempuh selama 38,83 detik dengan waktu tercepat ditempuh selama 29,48 detik pada lokasi parkir L1 R4 serta letakkan palet L1 R3. Sedangkan waktu terlama ditempuh selama 48,10 detik pada parkir L1 R1 serta taruh palet L10 R5. Berikut ini adalah gambar grafik dari pengujian akses keluar.

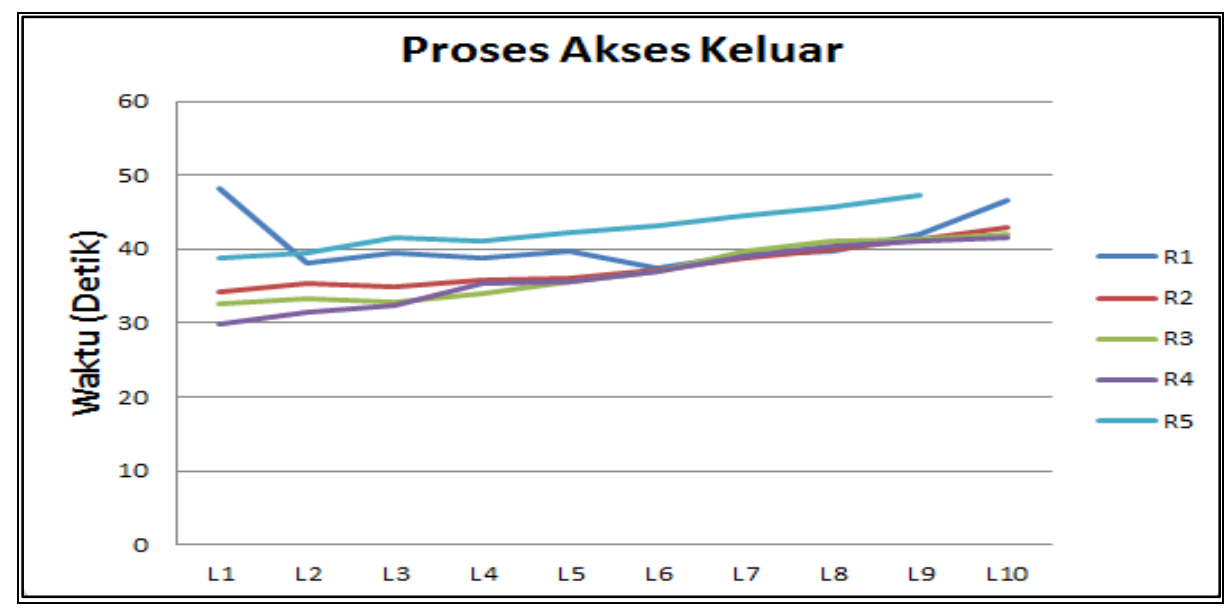

Gambar 21. Grafik pengujian akses keluar 


\subsection{Pengujian Respon SMS di dalam Ruangan}

Langkah Pengujian :

1. Tempatkan alat pada ruangan tertutup, diibaratkan tempat parkir berada diantara gedung-gedung tinggi yang menghimpitnya.

2. Pastikan Alat dalam kondisi hidup dengan mode Standby.

3. Masukkan kendaraan ke area parkir hingga terdeteksi oleh sensor 1 sebagai akses masuk atau dekatkan tangan anda pada sensor 2 hingga terdeteksi oleh sensor 2 sebagai akses keluar (uji coba dilakukan secara bergantian sesuai dengan akses yang diinginkan) kemudian buzzer akan bunyi 500ms.

4. Tunggu informasi suara akses masuk/keluar selesai sekitar 4 detik.

5. Tulis dan kirim SMS sesuai perintah dari interface HMI.

6. Hitunglah proses respon SMS masuk berdasarkan waktu menggunakan stopwatch dari awal terkirimnya SMS pada handphone hingga terbacanya oleh sistem dengan indikasi suara informasi akses masuk atau keluar.

7. Catat hasil pengujian respon SMS masuk

8. Tunggu proses sistem penyimpanan atau pengambilan selesai, hingga kondisi sistem kembali (standby) dan buzzer akan bunyi 1000ms, kemudian ulangi lagi sampai 10 kali percobaan untuk respon SMS masuk di dalam ruangan.

Dari hasil pengujian respon SMS di dalam ruangan pada akses masuk dan keluar, dimana respon SMS membutuhkan waktu yang berbeda-beda. Rata-rata waktu yang dibutuhkan untuk respon SMS di dalam ruangan selama 3,35 detik dengan waktu tercepat selama 2 detik. Sedangkan waktu terlama selama 6 detik. Berikut ini adalah gambar grafik dari pengujian respon SMS di dalam ruangan.

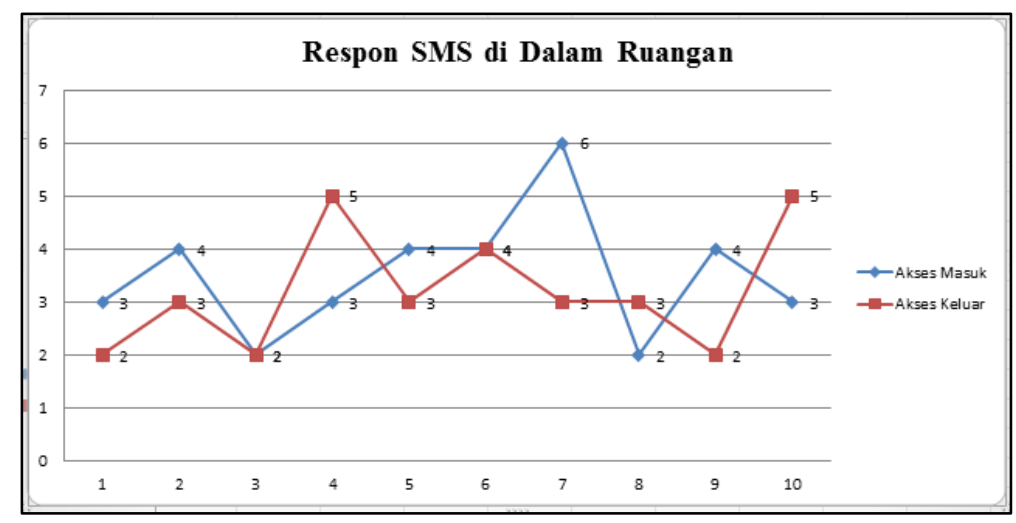

Gambar 22. Grafik pengujian respon SMS di dalam ruangan 


\subsection{Pengujian Respon SMS di luar Ruangan}

Langkah Pengujian :

1. Tempatkan alat pada ruangan terbuka, diibaratkan tempat parkir berada pada tempat yang tidak ada gedung tinggi di sekitarnya.

2. Pastikan alat dalam kondisi hidup dengan mode Standby.

3. Masukkan kendaraan ke area parkir hingga terdeteksi oleh sensor 1 sebagai akses masuk atau dekatkan tangan anda pada sensor 2 hingga terdeteksi oleh sensor 2 sebagai akses keluar (uji coba dilakukan secara bergantian sesuai dengan akses yang diinginkan) kemudian buzzer akan bunyi 500ms.

4. Tunggu informasi suara akses masuk/keluar selesai sekitar 4 detik.

5. Tulis dan kirim SMS sesuai perintah dari interface HMI.

6. Hitunglah proses respon SMS masuk berdasarkan waktu menggunakan stopwatch dari awal terkirimnya SMS pada handphone hingga terbacanya oleh sistem dengan indikasi suara informasi akses masuk atau keluar.

7. Catat hasil pengujian respon SMS masuk

8. Tunggu proses sistem penyimpanan atau pengambilan selesai, hingga kondisi sistem kembali (standby) dan buzzer akan bunyi 1000ms, kemudian ulangi lagi sampai 10 kali percobaan untuk respon SMS masuk di luar ruangan.

Dari hasil pengujian respon SMS di luar ruangan pada akses masuk dan keluar, dimana respon SMS membutuhkan waktu yang berbeda-beda. Rata-rata waktu yang dibutuhkan untuk respon SMS di dalam ruangan selama 3,20 detik dengan waktu tercepat selama 2 detik. Sedangkan waktu terlama selama 5 detik. Berikut ini adalah gambar grafik dari pengujian respon SMS di luar ruangan.

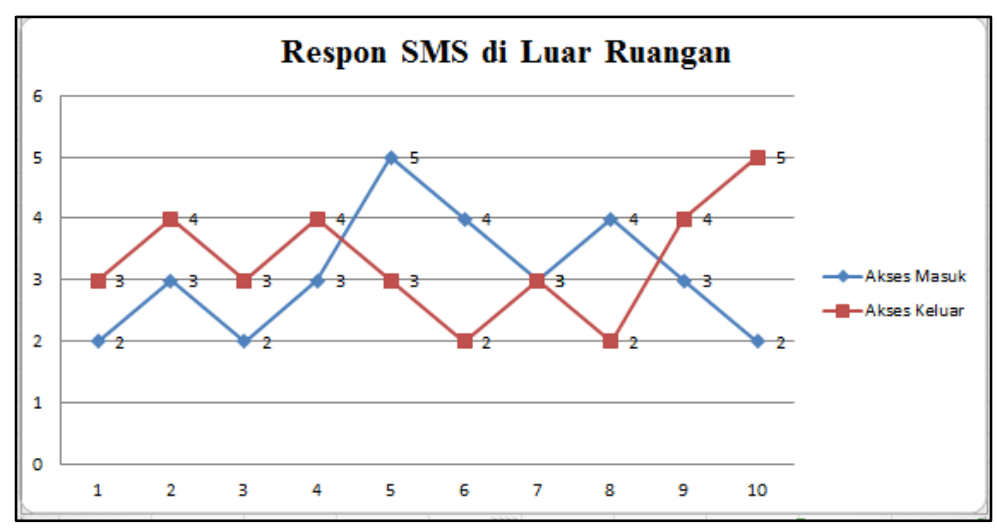

Gambar 23. Grafik pengujian respon SMS di luar ruangan 


\section{KESIMPULAN}

Berdasarkan hasil pengujian, respon SMS pada akses masuk dan keluar di dalam ruangan membutuhkan waktu rata-rata selama 3,35 detik. Sedangkan di luar ruangan membutuhkan waktu rata-rata selama 3,20 detik. Berdasarkan hasil pengujian, waktu yang dibutuhkan untuk menyimpan dan mengeluarkan kendaraan membutuhan waktu yang berbeda-beda, tergantung dari koordinat atau lokasi penyimpanan kendaraan sebelumnya. Waktu rata-rata yang dibutuhkan untuk proses penyimpanan atau akses masuk ditempuh selama 38,57 detik dengan waktu tercepat ditempuh selama 29,84 detik pada parkir L1 R4 serta ambil palet L1 R5 dan waktu terlama ditempuh selama 47,27 detik pada parkir L9 R5 serta ambil palet L10 R1.

Sedangkan Waktu rata-rata yang dibutuhkan untuk proses pengeluaran atau akses keluar ditempuh selama 38,83 detik dengan waktu tercepat ditempuh selama 29,84 detik pada parkir L1 R4 serta taruh palet L1 R3 dan waktu terlama ditempuh selama 48,10 detik pada parkir L1 R1 serta taruh palet L10 R5.

\subsection{Saran}

1. Penambahan sistem pembayaran pada parkir pintar bertingkat.

2. Terapkan dengan sistem SCADA pada alat ini, agar pengguna dapat memonitor parkir dan menghitung kapasitas parkir.

3. Sistem parkir pintar bertingkat ini tidak dilengkapi dengan sensor deteksi setiap slot penyimpanan sehingga penulis meminta kepada pihak yang ingin mengembangkan alat ini, sebaiknya tambahkan sensor deteksi untuk keamanan pengguna, jika sewaktuwaktu terjadi data error.

4. Modul SIM800L memiliki ketidakstabilan dalam menangkap sinyal apabila pada pemilihan provider tidak sesuai dengan kondisi tempat parkir. Oleh karena itu pemilihan provider sangat penting dalam penggunaan modul SIM800L yang digunakan dalam pembuatan sistem parkir.

5. Parkir pintar bertingkat ini bersifat miniatur atau prototype, apabila ingin direalisasikan maka perlu perhitungan secara khusus dengan beberapa para ahli dan membahas tentang massa berat mobil, torsi pada motor, mekanik yang digunakan, kontruksi bangunan serta lokasi tempat parkir untuk membangun area parkir pintar bertingkat ini. 


\section{DAFTAR PUSTAKA}

Arduino, Arduino Data sheets, www.arduino.cc

Eka Permana, Ridwan Hidayat. 2017. Rancang Bangun Sistem Keamanan Rumah Berbasis Sms Gateway Menggunakan Mikrokontroler, Jurnal Teknologi Informasi dan Komunikasi ISSN: 2252-4517 STMIK Subang, Oktober 2017.

Heri Andrianto, Agus Priono, Ratna Dewi. 2015. Menggambar Teknik Rangkaian PCB dengan Altium Edisi Revis. Modula.

Kadir, Abdul. 2014. From Zero to a Pro Arduino. Yogyakarta: Andi.

Kadir, Abdul. 2015. From Zero to Pro Pemrograman C. Yogyakarta: Andi.

L. Scott Hansen. 2013. Autodesk Inverter. Mc Graw-Hill Education

Mochamad Fajar Wicaksono, Hidayat. 2017. Mudah Belajar Mikrokontroller Arduino. Informatika.

Widodo Budiharjo. 2009. Membuat Sendiri Robot Cerdas Edisi Revisi. Elek Media Komputindo 